\title{
Problems in Roller Skating Teaching and Application of Related Teaching Methods
}

\author{
Juerui Wang \\ Department of Physical Education and Research \\ Xinjiang University \\ Urumqi, Xinjiang, China 830046
}

\begin{abstract}
Roller skating is deeply loved by students in colleges and universities in Xinjiang. Xinjiang University is the first university opening the selective course of roller skating in Xinjiang. It was in 1999. It has obtained various awards and honors. With many years of teaching accumulation, it has relatively mature experience. The selective course of roller skating is a special course of Xinjiang University and a postcard of Xinjiang University. By analyzing the problems in its roller skating teaching and applying related teaching methods, we can find the best solutions and paths. Different teaching methods could solve different problems in teaching, so that teachers can teach roller skating well. The school-based teaching materials of roller skating can be amended constantly in order to perfect the teaching outline and teaching plan. It helps students better understand the roller skating culture and love roller skating, and well links in-class activities with extracurricular activities. It can better solve the problem of insufficient class hour, cultivate students' self study ability, motivate them to practice actively and help them form good living habits. The selective course of roller skating becomes a special PE course of Xinjiang University, is an important part of sports culture of Xinjiang University and a postcard of Xinjiang University.
\end{abstract}

Keywords -roller skating teaching; problems, related teaching methods

\section{RESEARCH OBJECTS AND METHODS}

\section{A. Research Objects}

Students of 2015 in roller skating classes from three campuses (Main Campus, South Campus and North Campus) of Xinjiang University and students in the Roller Skating League of Xinjiang Colleges and Universities

\section{B. Research Methods}

The document literature method, the questionnaire method, the mathematical statistics method and etc.

\section{PRESENT SitUATION}

\section{A. Overview of the Roller Skating Course in Xinjiang University}

Xinjiang University opened the selective course of roller skating in 1999. After years of summary and accumulation, the teaching documents become basically perfect. There are

Fund Project: the Social Science Fund Project of Autonomous Region (14BTY105). teaching outline, teaching plan and school-based teaching materials (including textbooks), and the quantitative test content in each term. After three times of amendment the school-based teaching materials has been improved. In 2002, the school won the second prize of innovative teaching demonstration class in colleges and universities in Xinjiang, won the third prize of teaching contest and the third prize of teaching results in Xinjiang University. At the beginning, it was only opened in the main campus. Later it developed to the south campus and the north campus with synchronous teaching. The number of students increased from 160 to 150 in each campus.

Xinjiang University Roller Skating Team participated in the first session of college students' roller skating games in colleges and universities in Xinjiang in 2011. It won the first place in men's team and the second place in women's team, and got six championships in individual events. After this, it has the good achievements of taking all championships for several times in the contests organized by the University Union.

All campuses of Xinjiang University have set up a roller skating society. The roller skating society has gained the title of Top 10 Students' Society in 2015 in Xinjiang University.

The development of roller skating in colleges and universities in Xinjiang has reflected the love degree of college students on this sport. And it fully shows that roller skating is a sports event suitable for developing and popularizing among college students.

\section{B. Overview of the Roller Skating Course in Xinjiang University}

After Xinjiang University opened roller skating for two or three years, colleges and universities in Xinjiang also opened the selective course of roller skating one after another. The colleges and universities with good roller skating course are Heshizi University, Xinjiang University of Finance and Economics, Xinjiang Agricultural University, Xinjiang Normal University and Xinjiang Engineering College. The Xinjiang Colleges and Universities Education Department of the Autonomous Region only hold one session of roller skating games each year. But now the Roller Skating League of Xinjiang Colleges and Universities hold several times of activities and competitions every year. It is all organized by the rolling skating societies of each college and university, which 
gives full play to the role of the School Roller Skating Association. This year the Roller Skating League of Xinjiang Colleges and Universities organized and participated in the performance of Xinjiang's 60 Anniversary Activity. The team has been received by Secretary Zhang Chunxian and Director Liu Peng, and gotten the recognition of the leadership. They also participated in the sports festival activities on August 8, 2015. They have been invited to attend the opening ceremony of 13th National Winter Sports hosted by Xinjiang for performance. The roller skating achievements of colleges and universities in Xinjiang are closely associated with the cognition degree of college students on roller skating in colleges and universities in Xinjiang.

\section{ThE PROBLEMS IN TEACHING}

\section{A. Lack of Teaching Field and Facilities, and Insufficient Teaching Hours}

Behind brilliant achievements of Xinjiang University in roller skating, there is also helplessness. There is no indoor or outdoor field exclusive for roller skating in Xinjiang University. Xinjiang has a long winter (from November to May of the next year), so it is unable to play roller skating outdoors. The roller skating course of main campus is carried out in a $30 \mathrm{~m} 2$ basement. The course of south campus is also in basement, and students practice in plastics. The course of north campus is also in basement. The Top 10 Society of Xinjiang University has no field for activities. The conditions of other schools are also the same.

There are two terms of roller skating course in each year in Xinjiang University. There are 18 weeks of classes in each term (14 or 16 weeks of classes in some colleges) and 36 class hours. For the physical education of experiencing teaching, the teaching hours are obviously insufficient.

\section{B. Lack of Deeply Understanding on Roller Skating}

At the beginning of teaching, students may not be willing to equip with complete equipment, because they don't have enough knowledge on it. They lack self-protection ability, so they may get hurt if fall. Now the equipment manufacturing level is getting better and better. The price did not drop, but the quality is improved. For example, a pair of roller skating shoes was about $240 \sim 500$ yuan in the past ten years. Now it is also at this price. But the quality of the shoes is increased. They are more comfortable and conducive to learning roller skating. Students prefer a cheaper price psychologically. In fact, the cheaper shoes are of short service life. Before the end of the course students need to replace them, which is a great waste.

\section{Lack of Mental Preparation and Deep Technical Understanding, and Poor Physical Quality}

Students choose roller skating course, because they love it. Roller skating is thrilling, fresh and cool. It can meet the psychological needs of young college students. In college students' words, it is "speedy, thrilling and cool".

But students shall have certain conditions to play roller skating. Some students see other students play well, so they thought they could play well too. They buy a pair of roller skating shoes and start to play. After practice, some of them may be very sad, because it is not as easy as they imagine. Lacking perseverance, their attitudes change from love to boredom.

Now students, especially schoolgirls, lack coordination, balance and joint strength, and rarely exercise. The sport of roller skating needs certain strength, coordination, flexibility and balance. A lot of students don't have such physical quality.

The technique of roller skating subverts the exercise habits of people developing in their usual walk. The body structure, the direction of the force and force order are completely different. Now roller skating shoes is of good performance and skating quality, people first wearing the shoes may feel standing on accelerating car. It is difficult to keep balance. They may either skate immovably or not pull up.

\section{CONCLUSIONS AND SUGgestions}

\section{A. Putting Safety Awareness in the First Place}

In the course offering, the first class can be theory. It focuses on correct use and maintenance of roller skating equipment. Teachers can show students harms without wearing protective gears with multi-media (find some pictures and videos). Teachers can tell students how to choose a pair of good cost-effective roller skating shoes. At the same time, they shall require students to wear helmet, gloves, knee pads and elbow pads besides skating shoes. Otherwise don't allow them to participate in practical course (Stress that it is an iron law).

In arrangement of teaching methods, teach students how to use protective gears in first practical courses. Teach students self-protective actions: (1) lowering center of gravity; (2) advancing center of gravity; (3) kneeing down slowly; (4) supporting with hands on ground. It can avoid falling backwards or sidewards. If after step (1) and step (2) keep balance, it is not necessary to do step (3) and step (4). After wearing skating shoes, ask students practice the self-protective actions, until they can complete them unconsciously.

\section{B. Relying Mainly on Quality Practice While Taking Technical Training as Assistance}

Add some static exercises in technical training in order to increase the strength of students' knee joints and ankle joints, and students' knee joints and ankle joints could keep body balance in skating, avoiding hurt. Take rope skipping as one of test contents (160 time/min, for 100 points). After a period of training, students' joint strength will increase obviously. The increase of students' physical quality can guarantee that students can grasp relevant techniques correctly.

In technical teaching, do not overstress technical details. Only ask students lower the center of gravity and control the direction of force well. At the beginning, let students take much terrestrial imitation practice to help students do body posture and the skating action of single and double support well. After wearing skating shoes, ask students to keep lower gravity center, and stress the vertical state of single support leg and wheels perpendicular to the ground. 
In the teaching, add some gymnastics content to improve students' balance ability. For example, add the balance stand of gymnastics into roller skating course. Students maybe cannot do it at first. Through extensive practice, students will master it in the later period. It can improve students' one foot balance ability and help students grasp difficult technical actions, such as single leg support and double leg support, in skating techniques. Ask students practice split jump and matts jump in order to improve their coordination and flexibility. In order to meet students' pursuit for freshness, wonderfulness and specialty, on the basis of the racing roller skating teaching, add the technical content of freestyle slalom and speedy slalom, and also carry out the practice of various sudden stop techniques for students with good conditions. With high learning enthusiasm, students will desire to master some difficult technical movements.

By enhancing the physical quality of students, the technical training is guaranteed. It is better than simply to practice techniques. The data in tables below can show the teaching effect. "Table I", "Table II", "Table III"

TABLE I. Motivations of College StUdents In SELECTING ROLLER SKATING

\begin{tabular}{clllll}
\hline & $\begin{array}{c}\text { To } \\
\text { enhancin } \\
\text { ghysique }\end{array}$ & $\begin{array}{c}\text { To } \\
\text { grasp } \\
\text { exercise } \\
\text { method }\end{array}$ & $\begin{array}{c}\text { To know } \\
\text { the } \\
\text { culture of } \\
\text { roller } \\
\text { skating }\end{array}$ & $\begin{array}{c}\text { Hobbie } \\
\text { s and } \\
\text { interest } \\
\text { s }\end{array}$ & $\begin{array}{c}\text { To } \\
\text { impro } \\
\text { ve } \\
\text { comm } \\
\text { unicati } \\
\text { ons }\end{array}$ \\
\hline $\begin{array}{c}\text { The } \\
\text { number } \\
\text { of } \\
\text { students } \\
\text { \% }\end{array}$ & 41 & 101 & 29 & 218 & 117 \\
\hline
\end{tabular}

TABLE II. SATISFACTION OF COLLEGE STUDENTS ON ROLLER SKATING COURSE

\begin{tabular}{cllll}
\hline & $\begin{array}{l}\text { Satisfacto } \\
\text { ry }\end{array}$ & $\begin{array}{l}\text { Quite } \\
\text { satisfactory }\end{array}$ & $\begin{array}{l}\text { Gener } \\
\text { al }\end{array}$ & $\begin{array}{l}\text { Unsatisfa } \\
\text { ctory }\end{array}$ \\
\hline Teaching & 284 & 119 & 15 & 6 \\
content & 66.98 & 28.06 & 3.54 & 1.42 \\
$\begin{array}{c}\text { \% } \\
\text { Teaching } \\
\text { effect }\end{array}$ & 317 & 93 & 11 & 3 \\
\% & 74.76 & 21.94 & 2.59 & 0.71 \\
\hline
\end{tabular}

TABLE III. CHANGES OF PHYSICAL QUALITY BEFORE AND AFTER ROLLER SKATING CLASS

\begin{tabular}{|c|c|c|c|c|}
\hline & $\begin{array}{l}\text { Rope } \\
\text { jumping } \\
\text { before } \\
\text { class } \\
\text { Average } \\
\text { (min.) }\end{array}$ & $\begin{array}{l}\text { Rope } \\
\text { jumping } \\
\text { after } \\
\text { class } \\
\text { Average } \\
\text { (min.) }\end{array}$ & $\begin{array}{l}\text { Half } \\
\text { squat } \\
\text { before } \\
\text { class } \\
\text { Average } \\
\text { (min.) }\end{array}$ & $\begin{array}{l}\text { Half } \\
\text { squat } \\
\text { after } \\
\text { class } \\
\text { Averag } \\
\text { e } \\
\text { (min.) }\end{array}$ \\
\hline $\begin{array}{l}\text { The } \\
\text { number of } \\
\text { students } \\
\text { Average }\end{array}$ & $\begin{array}{l}424 \\
114\end{array}$ & $\begin{array}{l}424 \\
143\end{array}$ & $\begin{array}{l}424 \\
1 . .33\end{array}$ & $\begin{array}{l}424 \\
5.45\end{array}$ \\
\hline
\end{tabular}
skating out of interests, and they know the culture of roller skating deeply. Seen from "Table II", it is sure that students are satisfied on the roller skating course. "Table III" shows that students' physical quality is obviously improved by taking the roller skating course.

\section{Developing Students' Interests and Extending Classroom Teaching beyond Class}

Each campus can establish a roller skating society. They can divide students into several groups and organize students to participate in the group extra-curricular activities of roller skating. Old members lead new members to participate in activities. The school can include the attendance into the extracurricular achievement of final physical education. If the student is absent $1 / 3$ of time, this content has no source. Encourage students to participate in extracurricular activities, and help students form a good habit of exercise. It can make up for insufficient class hour in physical education, benefit student to participate in collective activities and exercise their body. Sport is a group game. We need to play together, sharing happiness, experiencing the feeling of sports and exchanging such feelings, to complete the whole process of physical education. Teachers can arrange students to analyze representative problems and find solutions in class. Let students fully participate in the teaching and become the teaching subject. Teachers control the teaching and adjust teaching atmosphere and pace, so that students become more interested in every link of teaching. Students become the real master in physical education. "Table IV"

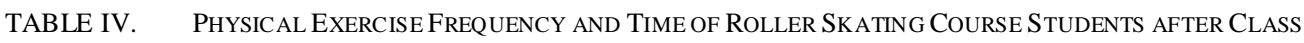

\begin{tabular}{|c|c|c|c|c|c|c|c|c|c|}
\hline Times per week & Never & 1 & 2 & $3>$ & Min/time & $30<$ & $30-60$ & $60-90$ & $90>$ \\
\hline The number of students & 7 & 51 & 71 & 295 & & 29 & 115 & 163 & 117 \\
\hline$\%$ & 1.65 & 12.03 & 16.75 & 69.58 & & 6.84 & 27.12 & 38.44 & 27.59 \\
\hline
\end{tabular}

\section{Increasing the policy support efforts}

Hope the school leaders can really guarantee the normal teaching of physical education, and include physical education into management scope as first-level discipline. The undergraduate teaching assessment of the Ministry of Education will take indoor and outdoor field areas into standard. Considering the development of 13th five-year plan of Xinjiang University, all indicators can keep up with domestic well-known colleges and universities, reaching the domestic advanced level. The school can provide plenty of exercise environments to students and faculty. Students in Xinjiang University love sports, so the school can carry out some key support sports which are popular and with developmental potential, and influential among colleges and universities in Xinjiang, such as roller skating. Roller skating is also popular in faculty of Xinjiang University, so the school can carry out this activity among students and faculty. The school should provide fields and funds, organize competitions, and guarantee normal teaching order and environment. 
Each roller skating class can establish a WeChat Group, and teachers can regularly make some micro-class and put on the WeChat Group. It enables students to interact with teachers timely. The modern communication technology is highly developed, and mobile phone function is very powerful now. We can make full use of modern communication terminal products. In each class take some video and send to students timely. Through a period of practice, students may see their progress and be encouraged. Teachers can arrange students with homework and ask students to put their completion conditions on WeChat Group. Then teachers can give timely direction and suggestions, forming a benign interaction relationship. The result of physical education should include both in-class performance and out-class performance in order to evaluate students' performance in physical education objectively and fairly.

Teachers also can send news of big games and videos to students, so students can know the development dynamic of roller skating timely. Students can really participate in the whole process of roller skating, and they can experience happiness from this sport. Students practice both in class and after class, and organize extracurricular activities. With guide and help of teachers, they expand the connotation and denotation of physical education, and understand the culture of roller skating. Such physical education can be fresh, alive and substantial, and students will love it and be willing to participate in the sports activities. It can help students form a good living habit. It fully shows that roller skating can meet the needs of colleges students, and is suitable for contemporary college students. It can lay a good foundation for students to build a healthy body and mind.

\section{REFERENCES}

[1] Jiang Yayu, Liu Shiwen. Methods and Approaches for Improvement of

[2] Wang Juerui (1963 ), male, Associate Professor, graduated from Harbin Institute of Physical Education. Native place: Harbin

[3] Research direction: Physical Education Teaching

[4] Contacts: 18999888681; 2350708835@qq.com;

[5] No. 14, Shengli Road, Tianshan District, Urumqi, Xinjiang Uygur Autonomous Region Zip code: 830046

[6] Work unit: Department of Physical Education and Research, Xinjiang University, Wang Juerui 